\title{
Targeting Alien Filmmakers in 1930s Hollywood
}

\author{
By J. Emmett Winn
}

Fall 2010 Issue of KINEMA

\section{TARGETING ALIEN FILMMAKERS IN 1930s HOLLYWOOD}

On January 28, 1933, the US government made its first strike in a much heralded drive to rid Hollywood of alien filmmakers. A special assistant to Secretary of Labour William Doak forecast "a wholesale exodus of foreign film talent" would begin. ${ }^{(1)}$ The news made front-page headlines across the country as government agents interrogated Australian-born screenwriter John Farrow and other Hollywood filmmakers. ${ }^{(2)}$ Labour Department special agents and local police arrested Farrow as he danced with South American actress Mona Maris at a fashionable Los Angeles hotel. ${ }^{(3)}$ His crime, according to the immigration special agents, was that he overstayed his legal visitor permit.

This study investigates the government's campaign against alien filmmakers in the early 1930s and finds that government promises to deport hordes of foreign workers were never serious, but were instead a project intended for publicity, both to show Americans that the Department of Labour was protecting jobs and to justify payments to special immigration agents through large governmental expenditures. The government's public attack on Hollywood immigrants was designed to stir up press coverage by attacking the motion picture industry while simultaneously making the secretary of Labour's secret service appear to deal with the serious unemployment problems in the United States during the early years of the Great Depression.

\section{Targeting Hollywood Aliens}

On October 6, 1932, the Los Angeles Times reported that special assistant to the Secretary of Labour, agent Murray W. Garsson, was in Hollywood investigating aliens. Labour Secretary William Doak explained that Garsson was doing "heavy investigation" on the West Coast. (4) "According to Garsson," a newspaper reported, "the United States government is in the fight against racketeers and aliens of the 'public enemy' type, and actors and actresses who have overstayed their visitor permits because of numerous complaints filed in Washington." ${ }^{(5)}$ It also was reported that while in Los Angeles, Garsson planned to meet with the police in charge of investigating communists. ${ }^{(6)}$ It is noteworthy that Hollywood actors were included with public enemies and communists, but Garsson reported that he was motivated to include actors in his investigations because of the many complaints received in Washington, DC, not because of any communist connection.

The complaints that sent Garsson after Hollywood aliens came from hearings in support of a House bill to limit the immigration of actors to America. ${ }^{(7)}$ Representative Samuel Dickstein (Democrat-New York) held hearings on a bill to restrict actors from immigrating to America. ${ }^{(8)}$ The bill (H. R. 8877) was designed "to clarify the application of the contract-Labour provisions of the immigration laws to actors." (9) During the hearings, Dickstein expressed critical concern for the starving American actors and their families who were displaced from their jobs by aliens. In questioning Charles Pettijohn, Motion Picture Producers and Directors of America (MPPDA) counsel, Dickstein asserted, "[F]rom indications and information received by this committee, it appears that your picture concerns have been importing hordes of aliens to take [American actors'] places." (10) Dickstein's bill was intended to make it very difficult for Hollywood to import alien actors unless the studios could prove that the foreign talent was exceptional. Before the bill was passed, the contract Labour provisions allowed Hollywood to hire foreign talent without stiff limitations. Dickstein found this unacceptable and accused Hollywood of importing foreigners under the pretext that they were actors: "The committee has evidence that there are between 500 and a thousand of these people who have been brought in under the term 'actor.' We are trying to prevent that horde of people being brought here under the guise of 'actors' and thus get around the contract Labour provision, and we want to get this fixed up so there will be no avoiding the contract Labour law." (11) The MPPDA opposed the bill because it "would work unwarranted hardships upon the motion-picture industry." ${ }^{(12)}$ One of the MPPDA's arguments against the bill was that many of Hollywood's finest foreign actors had not been outstanding talents when they first came to the United States but developed into exceptional talents in America. As proof of this argument, counsel Pettijohn provided examples of foreign-born players who had developed into great actors in America, 
including Maureen O'Sullivan, who originally came to the States as a child to play a role that required an accent. $^{(13)}$

The $72^{\text {nd }}$ House of Representatives debated Dickstein's bill to ensure that alien actors did not receive contracts for American jobs unless they were deemed to be "of distinguished merit and ability." (14) Dickstein argued, "I am presenting for the consideration of this House a real honest-to-goodness restriction measure that will save the American actor and his family from starvation." ${ }^{(15)}$ He continued to claim that Hollywood imported multitudes of aliens who were not professional actors but mere amateurs. Moreover, he argued that the United States had "been the 'suckers' for everybody," because other countries, such as England and France, refused to allow Americans acting jobs while, "on Broadway in New York to-day there are about 4 or 5 American actors, and there are over 250 aliens who have displaced Americans" on the stage. ${ }^{(16)}$ The House debated and passed Dickstein's bill. ${ }^{(17)}$ It appeared that relief was on its way to the unemployed and starving American actors were displaced by aliens.

Armed with Dickstein's complaints of hundreds of alien filmmakers, Garsson began the move on Hollywood with a great deal of press coverage. The press couldn't get enough of Garsson's high-profile West Coast targets, which included gangsters, actors, and communists. The New York Times charged that Garsson intended to investigate every foreign actor in Hollywood.(18) Garsson claimed there were as many as five hundred aliens in Hollywood who were probably illegal because they overstayed the six-month limit on their visitor permits. ${ }^{(19)}$ Garsson's press coverage was the perfect publicity for Secretary Doak's demands to Congress for additional funds to deport aliens. Doak enjoyed the press attention, beginning to see his claim to fame as the nation's deportation chief.

\section{Secretary of Labour William Doak's War on Immigrants}

Virginia Republican William Doak was appointed as President Herbert Hoover's secretary of Labour in December 1930 and served until he was replaced in early 1933 with President Franklin Roosevelt's secretary of Labour, Frances Perkins. Doak was the first native-born American to serve as Labour secretary. The son of a confederate soldier, Doak worked his way up through the ranks of the Brotherhood of Railway Trainmen to become a Labour leader. ${ }^{(20)}$

Doak's stint as Labour secretary came during the Great Depression, thus he faced the problem of high unemployment. Robert H. Zieger and Gilbert J. Gall argue that "by the fall of 1930, even government officials acknowledged that unemployment had soared over the 15 percent mark."(21) Doak's immediate answer to the problem was to protect American jobs by deporting illegal aliens and ceasing legal quota immigrations. In his first radio address to the nation, Doak expressed the plan, saying, "[M]y conviction is that by strict limitation and a wise selection of immigration we can make America stronger in every way, hastening the day when our population shall be more homogeneous." ${ }^{(22)}$ Doak's notion of homogeneity was a "race-based nativism" that favoured northern and western Europeans over eastern and southern Europeans and all people of colour, ${ }^{(23)}$ and he was not alone in his desire to keep American jobs for Americans and to make the United States less diverse. At the same time, Senator David Reed (R-PA) urged Congress to keep American jobs safe by "shut[ting] the gates" on immigration for two years. ${ }^{(24)}$

For several years, immigration was controlled through quotas that allowed a specific number of aliens from each country to immigrate to the United States based on the national origins principal. As David Montgomery explains, "The Immigration Act of 1924 authorized a board of scholars to determine the proportion of each European nationality, not among recent immigrants but 'in the national blood' by enumerating the 'national and linguistic stocks'" of the 1790s. ${ }^{(25)}$ The quota system, driven by imperfect data on the national origins of the American population, limited immigration and justified discrimination against southern and eastern European immigrants. ${ }^{(26)}$ Gary M. Walton and Hugh Rockoff argue that restricting immigration was partially the result of racism, because a "pseudo-scientific veneer" was used to suggest that native-born Americans were more intelligent and more capable. ${ }^{(27)}$ Therefore, the quota system was understandably controversial and hotly debated for several years, but Hoover proclaimed the quotas early in 1929 as one of his first presidential acts. ${ }^{(28)}$

The quota system was not the only way the Hoover administration sought to stop immigration. In the fall of 1930 the president invoked the "'likely to become a public charge' provision of the immigration statute," thus stopping most legal immigration under the quota system. ${ }^{(29)}$ The combined effects of the quota system 
and Hoover's embargo reduced new legal immigration levels significantly. Nonetheless, anti-immigration supporters knew that thousands of aliens remained in the United States and that the threat of illegal immigration still loomed.

Therefore, Hoover's appointment of Doak as secretary of Labour on December 9, 1930, came about in a stormy period of anti-immigration legislation and increasing institutional racism against aliens. Doak was no stranger to controversy. Hoover waited almost two years for Doak to become his Labour secretary, because the appointee was publicly denounced by several unions and did not have the support of the American Federation of Labour (AFL). ${ }^{(30)}$ The previous Labour secretaries came from the ranks of the AFL, a trend the powerful union organization wanted to continue. The National Association for the Advancement of Coloured People (NAACP) also strongly opposed Doak's appointment because of his racist views. ${ }^{(31)}$ One NAACP paper said, "[T]o put a man of this kind in the Cabinet as Secretary of Labour would be the grimmest joke ever perpetrated at the expense of a long suffering people." ${ }^{(32)}$ Privately, NAACP leaders were "convinced that Doak is thoroughly dangerous." (33) Doak soon legitimized the NAACP's fears. As he took residence in the Department of Labour, he began an immediate attack on the "foe within our doors," meaning the alien in the United States. ${ }^{(34)}$

By early 1931 the government's plan to deport aliens was in full swing. ${ }^{(35)}$ Doak reported that there were four hundred thousand unlawful aliens in the United States and that one hundred thousand of them were deportable. ${ }^{(36)}$ He was pleased by the support he received from Congress for his deportations and had the president's assurance that he would not lack funds to continue his efforts. ${ }^{(37)}$ With that support on February 14, Department of Labour agents and NYC police raided a Finnish Worker's Education Association dance and, in "an atmosphere of hysteria tinged with indignation," forced one thousand attendees to line up and prove they were in the country legally. ${ }^{(38)}$ Only eighteen failed to prove they were legal, but the strong-arm invasive tactics inspired concern among many, including Senator Robert Wagner (D-NY). Wagner wrote to Doak insisting that the raid was deplorable, but Doak responded that since the harsh methods were effective, their use would continue; ${ }^{(39)}$ Doak was often publicly defiant when his strong-arm methods were questioned. ${ }^{(40)}$

To help with his drives, Doak built a force of special immigration agents to help ferret out illegal aliens. During testimony before the House Subcommittee on Appropriations, he remarked on the successes of his special agents, "What you might call the secret service of our department. Those men are unattached [not assigned to a specific area or duty] and they have largely been responsible for unearthing these [immigration] rackets that are going on at the present time." ${ }^{(41)}$ The special agents were paid via a one-hundred-thousanddollar budget allocated through Section 24 of the Immigration Act to enforce the contract Labour laws. The budget was increased to two hundred thousand dollars a year in May 1932. ${ }^{(42)}$ For this reason, Doak's secret service also was referred to as Section 24 men, who were personal appointees of the secretary of Labour. At the peak of its power, Section 24 consisted of dozens of men who could go anywhere in the United States on secret service work for the Labour Department. ${ }^{(43)}$

By January 1932 Doak rode high as deportation chief. He promised that nationwide alien deportations would increase. ${ }^{(44)}$ Moreover, within two weeks he moved immigration agents across the United States to protect the borders against illegal immigrants gaining entrance into the country. ${ }^{(4)}$ He continued to enjoy support when he denounced before Congress the "alien enemies boring from within to undermine American institutions" and the "so-called reformers and liberals who, if they had sufficient power, would destroy our national life." (46)

The New York Times pointed out that Doak's main concern was the alleged menace of communist subversives. ${ }^{(47)}$ In late October, he gave a speech on how Republicans were the friends of immigrants at a Brooklyn high school. When a few protesters appeared, they were branded communists and arrested. One protester stood to say, "Mr. Doak, I am here to protest against the illegal deportation under your direction of thousands of workers." Before he could finish, five uniformed police "pounced on" the man as the host of the ceremonies yelled, "Eject that man. We want no communism here. If you want communism, have it in your own hall!"(48)

Doak remained intent on deporting as many aliens as he could by whatever means were available. He used his Section 24 men to freely roam the United States to find, interrogate, and deport aliens whenever possible. 
In the West, Asians and Mexicans were a particular target, ${ }^{(49)}$ but the immigrants of southern and Eastern Europe remained a focus of his nativist discrimination and hatred of communism.

Doak's top agent was Murray W. Garsson, an English born immigrant who was involved in film production in the early 1920s in the United States. In 1931 Doak appointed Garsson as special agent and charged him with finding illegal aliens. ${ }^{(50)}$ In August of that year, Garsson was involved in a New York investigation of government clerks who were bribed to issue reentry permits to aliens. ${ }^{(51)}$ In September, Garsson was in Chicago under Doak's orders to expand the government "campaign against widely known racketeers" and their smuggling of aliens into the United States from Canada. ${ }^{(52)}$ This campaign made headlines for several weeks, and the press encouraged readers to see the special agents as tough on organized crime rather than rough on humble Finnish workers and students. ${ }^{(53)}$

By 1932, Doak paid Garsson nine thousand dollars a year out of his discretionary Section 24 funds. In comparison, the rest of the Section 24 men were paid between twenty-one hundred and thirty-six hundred dollars a year. ${ }^{(54)}$ During hearings on the Labour Department's appropriations, the subcommittee chairman asked Doak about Garsson's high salary. Doak replied, "He is a special man . . . He has been assigned special work." (55) Doak felt that Garsson's work and the two-hundred-thousand-dollar budget allocation for Section 24 were important and argued for continued funding to the budget subcommittee. The result was that Doak kept his fund and Garsson kept his salary.

\section{Garsson's Hollywood Arrests}

On January 24, 1933, the Hollywood press reported that Hungarian-born Béla Lugosi was questioned and quickly proved to the special agents that he was a naturalized American citizen. ${ }^{(56)}$ Undaunted, Garsson predicted that his first arrest in the alien filmmaker campaign would come soon. ${ }^{(57)}$ Three days after his prediction, Garsson stepped up his film colony campaign by questioning the popular Irish actress Maureen O'Sullivan ${ }^{(58)}$ and arresting Australian John Farrow for overstaying his legal visitor permit. ${ }^{(59)}$ Interestingly, O'Sullivan and Farrow were romantically linked in the Hollywood gossip columns, and their romance was national news. ${ }^{(60)}$ Farrow was released on twenty-five-hundred-dollar bail awaiting his hearing set for the next week. ${ }^{(61)}$ The Washington Post reported that "agents said . . . action might be taken to return him to his alleged homeland - Australia - regardless of the condition of his permit." (62) A New York Times story reported that in 1931 the immigration service advised Farrow to leave the United States, and he travelled to Tahiti and England before returning to America with papers that described him as an "assistant consular attaché of one of the Balkan countries" in southeastern Europe. ${ }^{(63)}$ The story further explained that sixteen other filmmakers were questioned but that they agreed to leave the country and reenter legally, a practice that Garsson explained was the best way to handle these cases, because it saved the government time and money. ${ }^{(64)}$ Garsson appeared as a reasonable government agent by encouraging this frugal policy, but in reality the Department of Labour counted these voluntary exits and reentries as deportations, ${ }^{(65)}$ thus inflating the deportation numbers.

Garsson gave Maureen O'Sullivan a "clean bill of health" on January 30, 1933, but asserted that Farrow misrepresented himself as a "Rumanian envoy" on his visitor's application. ${ }^{(66)}$ On February 4, Farrow faced new "charges of perjury and moral turpitude" after a five-hour hearing with Garsson. ${ }^{(67)}$ Moreover, the Section 24 federal agents "announced they made seven arrests" that included Spanish actor Antonio Camuellas and Australian actor Sonny Ray for overstaying their visitor permits. ${ }^{(68)}$ Four days later, Farrow was indicted by a federal grand jury for making false statements on his entry permit. ${ }^{(69)}$ Farrow's lawyer pleaded that it was a mistake, as he neglected "to put certain information into one of the printed blanks pertaining to immigration." (70) On February 10, Farrow surrendered himself to the US Marshals, pleaded no contest in federal court, and was released with instructions to appear later for sentencing. ${ }^{(71)}$ On that same day, British actor Frank Atkinson and Russian singer Nick Mall were arrested for overstaying their visitor permits. ${ }^{(72)}$ Less than a week later, Garsson returned to Washington after announcing that he questioned two well-known Latin American actors, Mexican Gilbert Roland and Argentinian Barry Norton. Garsson hinted that "the investigations of Roland and Norton cover more than merely the technical status of their permits." (73) In less than three weeks, Garsson publicly named eight actors and one actress in his deportation investigations.

Less than a month after his arrest, John Farrow appeared before District Judge Harry A. Hollzer and explained that he was confused when he filed his papers for his visitor permit. ${ }^{(74)}$ The judge believed him 
and gave Farrow five years' probation and criticized special agent Garsson: "We have here a branch of the government which set itself up as policeman, prosecutor, court and jury. Such a condition opens the door to abuse." (75) After considerable press coverage, Garsson's Hollywood alien deportation crusade was over. His highly publicized campaign against Hollywood actors failed. However, it wasn't the federal courts that crushed him; Judge Hollzer's condemnation came after Garsson already lost the fight. Instead, Garsson was defeated by the new secretary of Labour.

\section{Secretary of Labour Frances Perkins and Section}

At her first general press conference on March 21, 1933, a few short weeks after Farrow's arrest and a few days before Judge Hollzer sentenced Farrow to probation, Frances Perkins, the new secretary of Labour, eliminated the department's secret service activities ${ }^{(76)}$ Earlier that month, she reviewed a report on the Section 24 fund that concluded: "The law specifically provides that all expenses of persons employed under the authorization contained in Section 24 must come within the particular allotment provided for in the law. From this brief statement it will be seen that it is absolutely essential, in order to stay within the appropriation, to immediately curtail practically all activities under this allotment, which can only be done by immediately separating from the Service virtually all of the employees now carried thereon."(77) Perkins dissolved Section 24 and gave the work back to the regular district officials of the Labour Department. She also stated that "she was alarmed at the expenditure of the $\$ 200,000$ fund and declared that she was forced to act promptly in the face of only $\$ 12,970$ remaining in the appropriation March 15."(78) Moreover, Perkins said "there had been built up a force of seventy-one persons [in Section 24] . . . that were engaging in a variety of activities concerning which very meagre reports were being made" and that many of the personnel were "off-station." (79) Garsson offered his resignation, but it was a symbolic act. He and his fellow agents at the Department of Labour were already finished.

\section{The Department of Labour's Public Attack on Hollywood}

The hordes of illegal aliens in Hollywood never materialized. According to figures offered by Doak, Dickstein, and Garsson, there should have been between two hundred and one thousand illegal alien actors in Hollywood. However, only nine names were ever mentioned in the press during Garsson's stay in Hollywood, including Lugosi and O'Sullivan, who were innocent of any misconduct and proved so immediately. Garsson alluded to a further sixteen unnamed actors who cooperated with his investigation, but only scant references are made to these individuals. Of the seven actors whom Garsson stated were guilty of overstaying their visitor permits, only John Farrow was sentenced for any wrongdoing. Likewise, the associated investigations of racketeers and public-enemy types were equally overplayed in the media while producing very few, if any, actual deportations in these groups. Thus, Murray Garsson and Section 24's work did not produce convictions of public enemy gangsters or Hollywood aliens as its publicity promised.

This result was inevitable because Doak spent thousands of dollars per year on activities designed to produce publicity about the efforts of the handpicked men in his Section 24 secret service rather than to attack illegal immigration because the media paid attention to these high-profile racketeering and Hollywood alien campaigns. Their stories made headlines across the United States at a time when Americans faced soaring unemployment. For Doak, publicizing sensational alien-deportation campaigns was a way to generate public support. His attacks on groups such as Finnish workers and college students drew harsh criticisms from a variety of groups, including government officials. But no one seemed concerned when his secret service investigated so called public enemies and Hollywood aliens. These highly publicized cases didn't result in many real deportations, but they may have helped to keep the public distracted while Doak's other deportation campaigns continued. ${ }^{(80)}$

Not everyone was misled by Doak's press tactics. In her first press conference, Secretary Perkins "said that she had tossed overboard all the 'ballyhoo' in connection with the department's recent campaign against alien racketeering." (81) Likewise, the president of the US Immigration Inspectors Association celebrated the end of Section 24 by issuing a bulletin to its one thousand inspector members stating that "the activities of the Garsson force were more productive of publicity than of tangible results and cost the government more than $\$ 200,000$ a year." ${ }^{82)}$ Perkins biographer George Martin suggests that "it seemed likely there would be lots of publicity for the investigators and high living at government expense" in Hollywood. ${ }^{(83)}$

The Hollywood studios understood Garsson's publicity goals and never took his promise to deport hundreds 
of alien actors seriously. On February 5, about a week after Garsson launched his Hollywood campaign, a Los Angeles Times article explained the minuscule threat: "Stars in the big companies are not much affected. The [Hollywood studios] themselves know the immigration rules, and handle all such matters as proper entry, and the privilege of remaining here." ${ }^{(84)}$ Besides, the studios had something bigger to worry about: Representative Dickstein's bill to force the immigration contract Labour laws to apply to actors would have been an overwhelming blow to the film industry. In fact, the same news article makes the point: "There is a much stricter bill, called the Dickstein, regarding immigration of actors that has been for some time impending . . . This would prove very devastating to importations of players." ${ }^{(85)}$ While Garsson was in Hollywood, Dickstein's bill passed the House and was under debate in a Senate committee. The Hollywood industry had little to fear from Garsson but much to fear from Dickstein's bill.

However, on February 17, as Farrow waited for his day in court, the Senate Subcommittee on Immigration held hearings on the Dickstein bill. The hearing was in dramatic contrast to the warm reception the bill received in the House. No one appeared to speak in favour of the bill, and it took the subcommittee only a short while to decide that the impetus for the House bill was a single complaint in retaliation for Hollywood hiring foreign talent. ${ }^{(86)}$ New York Tenth District Representative Emanuel Celler summarized the bill's beginnings: "So it was just a mere letter written by a few men in the Lambs Club who were apparently without employment and thought it would be a means by which they might achieve some sort of position."(87) With no tangible support and a belief that the bill was motivated by retaliation; the Dickstein bill, as it had become known, died in Senate committee. ${ }^{(88)}$

\section{Garsson's Personal Reasons}

Among the nine actors Garsson questioned, three were Latin (Spanish, Mexican and Argentinean), two were Eastern European (Russian and Hungarian), two were Australian, one was Irish, and one was English. From a native origins principal position, investigating the three Latin actors, the Irish actress, and the two Eastern European actors easily is understood. However, Farrow was Australian. Of course, it is possible that someone in Section 24 actually believed that Farrow was a Rumanian envoy, as his permit stated, or, even more probably, saw Farrow's alleged Rumanian ties as good publicity. There is some support for this interpretation, as newspapers quoted federal agents calling Australia Farrow's "alleged homeland"(89) and asserted that Farrow was "allegedly a native of Australia." (90) This implies that the Rumanian connection may have been played-up for the press. Regardless, the newspaper accounts make it clear that Garsson wanted to charge Farrow. ${ }^{(91)}$ Garsson's determination likely grew from several factors.

Garsson's most compelling reasons for focusing on Farrow were financial, as Garsson's FBI file suggests that Garsson attempted to make money on the side. On March 16, 1933, Judge Hollzer requested an FBI investigation of Garsson in relation to his conduct as special assistant to the secretary of Labour in the Farrow case. ${ }^{(92)}$ Two days later, Secretary Perkins gave the FBI the okay to investigate Garsson. ${ }^{(93)}$ Judge Hollzer's request emanated from the suspicion that Garsson behaved inappropriately and that he was involved in criminal behaviour such as a "fee split" or blackmail. ${ }^{(94)}$ In an interview with two FBI special agents in Los Angeles, Hollzer explained that Garsson's handling of the case was irregular. Farrow reported that Garsson denied him counsel both after his arrest and during his first secret hearing with immigration officials. Farrow asked several times if he could contact his personal attorney but was told each time that he was not allowed counsel. ${ }^{(95)}$ In between questioning sessions, Farrow received a call from Roger Marchetti, a Los Angeles lawyer whom Farrow knew socially. Marchetti explained that he had information relevant to Farrow's case. Marchetti accompanied Farrow to his client's second questioning session with Garsson. At this meeting, Farrow once again asked for his personal lawyer, but this time Garsson suggested that Farrow could have Marchetti represent him and that if he became dissatisfied, he could switch to his personal lawyer later. ${ }^{(96)}$ Farrow felt this was a "shake down," (97) and Judge Hollzer thought that Garsson and Marchetti might have colluded in an illegal "fee split" so that Garsson would receive half of the money for Marchetti's services that Farrow would pay. After the questioning sessions, Garsson insisted that the evidence against Farrow be presented to the grand jury, which returned an indictment against Farrow. ${ }^{(98)}$

Judge Hollzer's suspicions were piqued when Garsson, Marchetti, and Farrow appeared before him after the indictment and Marchetti requested that the judge consider the case immediately in chambers. Moreover, Garsson suggested that the case called for leniency. Hollzer explained to the FBI agents that a request for leniency seemed very unusual because of the high-profile nature of the case. The judge elucidated that 
Garsson, a high-ranking government official from Washington, travelled to Los Angeles with a goodly amount of publicity, arrested Farrow in a very public manner, insisted on the grand jury hearing the case, and received an indictment. Therefore, it seemed odd that he immediately would request leniency. Hollzer dismissed the request that the case be handled in chambers and opted for open court. ${ }^{(99)}$ His eventual probation decision in Farrow's case was lenient because the facts suggested leniency, not because of Garsson's request.

The FBI file on Garsson also contains interesting statements concerning his activities during the time of his campaign to rid Hollywood of the alien actors. Apparently Garsson spent a good deal of time at Hollywood studios during this period, especially at Fox, ${ }^{(100)}$ Warner Bros., and MGM. ${ }^{(101)}$ It was thought that Garsson might position himself as a special advisor on alien matters to the Hollywood studios as a result of his alien actors' campaign publicity. ${ }^{(102)}$ Although this may not have materialized, Garsson's relationship to important Hollywood studio executives suggests that he did benefit in material ways. Testimony from 1943 in the FBI file states that he made large sums of money from the Hollywood stars and their studios and that he was helpful in arranging visas. ${ }^{(103)}$ In a memorandum to FBI Director Hoover, Frank M. Parrish, acting head of the Criminal Division of the Department of Justice, wrote that it was reported that Garsson "arranged a contract [with the Hollywood studios] whereby he would protect and represent the rights of foreign motion picture actors . . . [for] an annual salary of $\$ 100,000 . "(104)$

These allegations appear to have support, as Garsson knew Winfield Sheehan, an executive at Fox studios, for approximately twenty years; he also had a relationship with Louis B. Mayer; and Harry Warner, president of Warner Bros., lent him fifteen thousand dollars, supposedly on the promise that Garsson could do favours for Warner's interests. ${ }^{(105)}$ An unnamed employee of Twentieth Century Fox, probably Sheehan, admitted to the FBI that "he had loaned money to Garsson on several occasions and had also transferred certain Twentieth Century Fox dividends to Garsson . . . [And] stated that Garsson while employed by the Labour department had arranged a few visas for people interested in the motion picture industry."(106)

Furthermore, Farrow's reputation as a womanizer may have played a role in Garsson's attention. The press often referred to Farrow's many relationships with different actresses. ${ }^{(107)}$ What made his romancing especially objectionable to some was that it was suggested that he divorced his first wife and was not properly supporting their child. ${ }^{(108)}$ This situation may have contributed to Section 24 agents saying they may deport Farrow regardless of the condition of his permit, ${ }^{(109)}$ or this non-chivalrous behaviour might have contributed to the moral turpitude rap that Garsson tacked onto Farrow's charges. ${ }^{(110)}$ Regardless, the press pointed out Farrow's past misconduct and Judge Hollzer made it a provision of Farrow's probation that he "live up to the terms of his agreement with his divorced wife . . . wherein he undertakes to provide support for their child." (111) Garsson's FBI file also includes references to Farrow's womanizing and suggests that because of his illicit relations, he was not liked by studio executives and that perhaps Garsson was attempting to "assist some of the motion picture executives in getting rid of some alien actors under contract, which were not desired to be retained by the studios." ${ }^{\prime 112)}$

In the end, there is no definitive answer for why Garsson targeted Farrow, but rather a series of reasons, including Farrow's prior immigration problems, his high-profile relationship with O'Sullivan, his personal life, and the probability that Garsson would benefit financially through some relationship or another with Hollywood studio executives.

It is not clear what Garsson planned for his Hollywood alien sweep after Farrow, because Secretary Perkins shut down Section 24 almost immediately upon taking office. This period in Hollywood history might have been more controversial if Section 24 and Garsson was allowed to continue, but even in its brief life, it is a clear example of the ability of government officials to use Hollywood publicity in order to direct public attention against individuals whom they consider suspect.

\section{Conclusions}

The Hollywood alien immigration campaign was nothing more than an expensive publicity stunt and a shakedown. William Doak did it for the publicity, and Murray Garsson did it for the money, both the legal but ill-spent nine thousand dollars in salary and the illegal (or at best unethical) funds that he probably made on the side.

When Secretary Doak died in the fall of 1933 of a heart attack, ${ }^{(113)}$ Frances Perkins went on to help the 
New Dealers make drastic changes in US social policy. The Labour Department did not follow up with any further action against the remainder of the Hollywood actors named by Garsson in his investigation.

Various news stories suggested that Garsson resigned either just before or soon after Secretary Perkins closed Section 24, but they do not tell the whole story of his departure from the Department of Labour. Soon after disbanding Doak's secret service, Perkins decided to do some office work one evening. When she arrived at the empty Labour Department building, she heard voices coming from a fourth-floor room. She inquired about the noise to the security guard, who explained that it was Garsson and his agents. Perkins confronted the men, who claimed to be collecting their personal effects but were actually ransacking the department's files. Despite their menacing attitudes, Perkins ordered them to leave, and the men left without the stacks of papers and files they removed from the file cabinets. ${ }^{(114)}$

Thus Murray Garsson's association with the Department of Labour and former Secretary Doak ended. Garsson, who by most accounts was dishonest, continued his unethical ways. ${ }^{(115)}$ The FBI continued its inquiries into his actions long after Farrow's trial was over, but no FBI decision was ever made concerning his alleged misconduct in the Farrow case, and no criminal or civil charges were ever brought against either Garsson or Marchetti in relation to Farrow's case. Although Garsson's FBI file officially begins in March 1933, it contains information and interview testimony going back as far as the early 1920s, when he was supposedly a bootlegger during Prohibition. One allegation states that after Prohibition, Garsson "went into the business of 'furnishing blondes' particularly to Louis B. Mayer." (116) Later reports accused him of smuggling arms and aliens, being a gangster associate, racketeering, and other crimes, including extortion. ${ }^{(117)}$ Finally, in the 1940s Garsson and his brother set up a fake manufacturing company and bribed Kentucky congressman A. J. May to help them receive millions of dollars in government contracts during World War II. Hamilton-Dryden explains, "The Garsson brothers and former congressman from Kentucky, A. J. May were brought to trial in the Federal District Court of the District of Columbia in May 1947."(118) All were found guilty "of conspiracy and bribery" (119) and sentenced to prison terms of eight to twenty-four months. ${ }^{(120)}$ Garsson served eighteen months and was released from the Danbury, Connecticut, federal correctional institution in July 1951. ${ }^{(121)}$ He died a sick, homeless, broken man in 1957. ${ }^{(122)}$

Of course, this was not the last time that Hollywood was threatened by the government for harboring undesirables or un-American viewpoints. Interestingly, Martin Dies (D-TX) served on the Committee on Immigration and Naturalization that Dickstein chaired in the 72nd Congress. In 1941 Dies chaired the House Committee on Un-American Activities that investigated subversive activities in Hollywood. In comparison to later investigations, Garsson's attack on Hollywood is almost quaint, but its significance is its role as an early example of a political attack on Hollywood designed to generate publicity and support for discriminative purposes.

\section{Acknowledgments}

I am grateful to the following archivists and librarians for their great help in this research: Barbara Bishop, Auburn University; Kevin Proffitt, American Jewish Archives; Tab Lewis, National Archives and Records Administration, College Park, Maryland; Matthew C. Hanson, Franklin D. Roosevelt Presidential Library; Matthew T. Schaefer, Herbert Hoover Presidential Library; and Stacey Cisneros, Batavia Public Library, Batavia, Illinois.

\section{Notes}

1. "Alien Film Folks Face Deportation," Alabama Journal, January 28, 1933, 1.

2. Ibid.; "Question Maureen O'Sullivan about Stay in America," Coshocton [Ohio] Tribune, January 30, 1933, 5; "Wider Drive to Bar Hollywood Aliens," New York Times, January 29, 1933, N1.

3. "Alien Film Folks," 1.

4. Congress, House, Committee on Immigration and Naturalization, To Return to the Philippine Islands Unemployed Filipinos, 72nd Cong., 2nd sess., January 18, 1933, 7.

5. "Operations of Eastern Liquor Racketeers Using Convoyed Trucks under Investigation," Los Angeles 
Times, October 6, 1932, A18; "Hunt Aliens in Hollywood," New York Times, October 6, 1932, 14.

6. "Operations of Eastern Liquor Racketeers," A18.

7. The Section 24 group did not keep detailed records of their investigations.

8. E. P. Hutchinson, Legislative History of American Immigration Policy, 1798-1965 (Philadelphia: University of Pennsylvania Press, 1981), 186.

9. Congress, House, Committee on Immigration and Naturalization, Actors under Contract Labour Provisions of the Immigration Laws, 72nd Cong., 1st sess., February 24, 1932, 1.

10. Ibid., 4.

11. Ibid., 26.

12. Ibid., 24.

13. Ibid., 20.

14. Congressional Record, April 18, 1932, 72nd Congress, 1st sess., 8434.

15. Ibid.

16. Ibid., 8435 .

17. Hutchinson, Legislative History, 222.

18. "New Check Started on Aliens in Films," New York Times, January 19, 1933, 11.

19. "Film Aliens Face Quiz," Los Angeles Times, January 19, 1933, 1; "Expert Off to Quiz Hollywood Aliens," Washington Post, January 19, 1933, 2; "New Check Started," 11.

20. "Labour Secretary Again from Union Ranks," Business Week, December 10, 1930, 6-7.

21. Robert H. Zieger and Gilbert J. Gall, American Workers, American Unions: The Twentieth Century, 3rd ed. (Baltimore: Johns Hopkins University Press, 2002), 50.

22. Address by Honourable W. N. Doak, US Secretary of Labour, Collier's Radio Hour, Sunday, January 4, 1931, Hoover Presidential Papers, Cabinet Series, Labour Dept. Correspondence, 1931, file 15, Herbert Hoover Library.

23. Mae M. Ngai, "The Architecture of Race in American Immigration Law: A Reexamination of the Immigration Act of 1924," Journal of American History 86 (June 1999): 69.

24. "American Jobs for Americans," Literary Digest, December 30, 1930, 11.

25. David Montgomery, "Racism, Immigrants, and Political Reform," Journal of American History 87 (March 2001): 1270.

26. Ngai, "Architecture of Race," 73.

27. Gary M. Walton and Hugh Rockoff, History of the American Economy, 8th ed. (Fort Worth, TX: Dryden Press, 1998), 498.

28. Ngai, "Architecture of Race," 69.

29. Irving Bernstein, The Lean Years: A History of the American Worker, 1920-1933 (Boston: Houghton Mifflin, 1960), 305.

30. Robert S. Allen, "One of Mr. Hoover's Friends," American Mercury, January 1932, 53-62.

31. Walter White to Herbert A. Hoover, January 21, 1930. Papers of the NAACP, Group 1, Box 394, text-fiche reel 24, fr. D654-D677 (Frederick, MD: University Publications of America, 1990).

32. "The 'Brotherhood' of Railway Trainmen," The Crisis, March 1929. Papers of the NAACP, Group 1, 
Box 394, text-fiche reel 24, fr. D654-D677 (Frederick, MD: University Publications of America, 1990).

33. Walter White to James A. Cobb, 21 January 1930. Papers of the NAACP, Group 1, Box 394, text-fiche reel 24, fr. D654-D677 (Frederick, MD: University Publications of America, 1990).

34. Allen, "One of Mr. Hoover's Friends," 57.

35. Robe Carl White to Herbert A. Hoover, May 14, 1931, Presidential Papers Cabinet, Labour Dept. Correspondence, May-August 1931, Herbert Hoover Presidential Library. This letter is a report prepared by Acting Secretary of Labour White, who is pleased to report that immigration had decreased and deportations increased in the preceding months.

36. "Says 400,000 Aliens Are Here Illegally," New York Times, January 6, 1931, 5.

37. Gardner Jackson, "Doak the Deportation Chief," The Nation, March 18, 1931, 295-96.

38. "18 Aliens Seized at Finnish Dance," New York Times, February 16, 1931, 17.

39. Jackson, "Doak the Deportation Chief," 296.

40. Allen, "One of Mr. Hoover's Friends," 59.

41. Congress, House, Subcommittee of House Committee of Appropriations, Department of Labor Appropriation Bill for 1933, 72nd Cong., 1st sess., January 26, 1932, 41.

42. Hutchinson, Legislative History, 223.

43. Congress, House, Subcommittee of House Committee on Appropriations, Department of Labour Appropriation Bill for 1934, 72nd Congress, 2nd sess., December 16, 1932, 38.

44. "20,000 to Be Deported in 1932, Doak Estimates," New York Times, January 7, 1932, 10.

45. "Doak Shifts Forces in Alien-Running War," New York Times, January 22, 1932, 7.

46. "D. A. R. Asks Jobless Aliens Be Deported under Presidential Decree of Emergency," New York Times, April 22, 1932, 1.

47. Ibid., $1,11$.

48. "Doak Heckled Here," New York Times, October 29, 1932, 10.

49. "First Arrest Expected Today in Federal Campaign Against Aliens Who Evade Laws," Los Angeles Times, January 26, 1933, A2.

50. There were few records kept by the Department of Labour on these special agents; therefore, it is not exactly clear when Garsson joined the department. The first mention of his name occurs in the summer of 1931. A confidential letter from Republican National Committee member Charles D. Hilles to Walter Newton, secretary to President Hoover, asks, "[C]an you ascertain for us who made representations to the Administration that resulted in the appointment of Murray W. Garsson as 'Special Assistant Secretary of Labor?" Penciled on the letter is "Friend Chas. Barrett," but a later source suggests that New York Representative Samuel Dickstein sponsored Garsson. Charles D. Hilles to Walter Newton, June 17, 1931, Presidential Papers, Cabinet, Labour Dept. Correspondence, April-July 1931, Herbert Hoover Presidential Library. "Murray Garsson's Suckers," Time, August 12, 1946, 15. It is possible that both Barrett and Dickstein sponsored Garsson to Doak.

51. "Two More Arraigned in Alien Smuggling," New York Times, August 7, 1931, 34.

52. "19 Seized in Ring Smuggling Aliens," New York Times, September 9, 1931, 21.

53. "Alien 'Racket' Source Traced by Garsson," New York Times, September 28, 1931, 3; "Dr. Carmen Ferraro Held as a Smuggler, New York Times, October 11, 1931, 26; "Another Alien 'Enemy' Held," Los 
Angeles Times, November 5, 1931, 6; "Alien Drive Nets 44 in 3 Months," Washington Post, November 13, 1931, 7; "Asserted Alien Ring Indicted," Los Angeles Times, November 28, 1931, 3.

54. Congress, Labor Appropriation Bill for 1934, 38.

55. Ibid.

56. "Actor Shows Citizenship," Los Angeles Times, January 25, 1933, A8.

57. The article implies that Farrow will be the one arrested, as it references his past entry to the United States as a sailor. "First Arrest Expected," A2.

58. "Wider Drive," N1.

59. "Alien Film Folks," 1.

60. "Farrow Upsets Young Dreams," Newark Advocate, January 29, 1933, 5.

61. "New Alien Drive Round-Up Near," Los Angeles Times, January 28, 1933, A1.

62. "No Title," Washington Post, January 29, 1933, 3.

63. "Wider Drive," N1.

64. Ibid.

65. Congress, Labor Appropriation Bill for 1934, 21.

66. "Clear Maureen," Mansfield [Ohio] News-Journal, January 30, 1933, 1.

67. "New Counts to be Faced by Farrow," Los Angeles Times, February 4, 1933, 12.

68. Ibid.

69. "Screen Writer Faces Charges," Los Angeles Times, February 9, 1933, A1; "Farrow Faces Inquisition," Los Angeles Times, February 8, 1933, A3.

70. "Screen Writer Faces Charges," A1.

71. "Russian Singer Held as Alien," Los Angeles Times, February 10, 1933, A3.

72. Ibid.; "Seize Alien Film Stars," New York Times, February 11, 1933, 10.

73. "Screen Actors in Alien Inquiry," Los Angeles Times, February 16, 1933, A1.

74. "Farrow to Learn His Fate Today," Los Angeles Times, February 20, 1933, A10.

75. "Screen Writer Wins Probation," Los Angeles Times, March 28, 1933, A16.

76. "55 Out as Federal Shake-Up Is Started by Miss Perkins," Washington Post, March 22, 1933, 1; "Miss Perkins Cleans House," Los Angeles Times, March 22, 1933, 3.

77. "Section 24 Fund- $\$ 200,000$," Labour Department Records, Administrative Appropriations, 1933-35, National Archives and Records Administration, College Park, MD. An account of the report Perkins reviewed can be found in George Martin, Madam Secretary Frances Perkins (Boston: Houghton Mifflin, 1976), 28-29.

78. "55 Out," 3.

79. "Reforms Begun by Miss Perkins," New York Times, March 22, 1933, 3.

80. Congress, Labour Appropriation Bill for 1933,; Congress, Labour Appropriation Bill for 1934, 72nd Congress, 2nd sess., December 16, 1932; Congress, House, Subcommittee of House Committee on Appropriations, First Deficiency Appropriation Bill for 1933, 72nd Cong., 2nd sess., December 23, 1932; Congress, 
To Return to the Philippine Islands Unemployed Filipinos, 72nd Cong., 2nd sess., January 18, 1933.

81. "Miss Perkins Cleans House," 3.

82. "Reforms Begun," 3.

83. Martin, Madam Secretary, 27.

84. "Foreign Actors in Panic at Deportation Threat," Los Angeles Times, February 5, 1933, A1.

85. Ibid.

86. Congress, Senate, Subcommittee of the Committee on Immigration, Application of Contract-Labour Provisions of Immigration Laws to Actors, 72nd Cong., 2nd sess., February 17, 1933, 2.

87. Ibid, 15 .

88. Hutchinson, Legislative History, 222.

89. "No Title," 3.

90. "Alien Film Folks," 1.

91. "New Counts," 12.

92. J. E. P. Dunn, FBI Special Agent in Charge, Los Angeles, California, to Director FBI, Washington, DC (telegram), March 16, 1933, FBI Headquarters file 62-28422, Federal Bureau of Investigation, Washington, DC (hereafter, FBI file 62-28422).

93. F. M. Parrish, Acting Head, Criminal Division, Department of Justice, Washington, D.C. to FBI Director (memorandum), March 18, 1933, FBI file 62-28422.

94. Memorandum for the Special Agent in Charge, J. E. P. Dunn, Los Angeles, California, March 16, 1933, FBI file 62-28422.

95. J. E. Hoover, FBI Director, Washington, DC, to F.M. Parrish, Acting Head, Criminal Division, Department of Justice, Washington, DC (memorandum), April 4, 1933, FBI file 62-28422.

96. Ibid.

97. P. E. Foxworth, FBI Headquarters, Washington, DC, to J. E. Hoover, FBI Director, Washington, DC (memorandum), May 19, 1935, FBI file 62-28422.

98. Memorandum for the Special Agent in Charge, J. E. P. Dunn, Los Angeles, California, March 16, 1933, FBI file $62-28422$.

99. Ibid.

100. Hoover to Parrish (memorandum), April 4, 1933, FBI file 62-28422.

101. Memorandum to L. B. Nichols, February 2, 1943, FBI file 62-28422.

102. Hoover to Parrish (memorandum), April 4, 1933, FBI file 62-28422.

103. Memorandum to L. B. Nichols, February 2, 1943, FBI file 62-28422.

104. Frank M. Parrish, Acting Head of the Criminal Division, Department of Justice, to J. E. Hoover, FBI Director (memorandum), April 3, 1933, FBI file 62-28422.

105. Memorandum to L. B. Nichols, February 2, 1943, FBI file 62-28422.

106. Report on Murray W. Garsson, July 8, 1946, FBI file 62-28422.

107. Alien Film Folks," 1.

108. Harrison Carroll, "Behind the Scenes in Hollywood," Monessen [Pennsylvania] Daily Independent, 
December 20, 1932, 5 .

109. "No Title," 3.

110. "New Counts," 12.

111. "Screen Writer Wins," A16.

112. Hoover to Parrish, (memorandum), April 4, 1933, FBI file 62-28422.8.

113. "William N. Doak Dies in Virginia," New York Times, October 24, 1933, 21.

114. Naomi Pasachoff, Frances Perkins: Champion of the New Deal (New York: Oxford University Press, 1999), 81-82; Martin, Madam Secretary, 35-36.

115. Martin, Madam Secretary, 25-26.

116. Foxworth to Director FBI, June 16, 1939, FBI file 62-28422.1.

117. Tris Coffin, "Washington Peep Show," The Nation, August 3, 1946, 120; "Murray Garsson's Suckers," Time, August 12, 1946, 15.

118. John Hamilton-Dryden, "The Garsson-May Connection: An Account of War Profiteering in Batavia, Illinois," 27, Special Collections, Batavia Public Library, Batavia, Illinois. This is an excellent treatment of the trial and evidence.

119. "May and 2 Garssons Guilty of Conspiracy and Bribery," Washington Post, July 4, 1947, 1.

120. "Wife Gets Divorce in Mexico from Murray Garsson," Washington Post, October 17, 1952, 50.

121. "Murray Garsson's Wife Takes Overdose of Pills," Washington Post, July 16, 1951, 1.

122. "Murray Garsson Dies in Poverty," New York Times, March 28, 1957, 32.

\section{Author Information}

J. Emmett WINN is Professor in the School of Communication and Journalism at Auburn University (Alabama). He is the author of Documenting Racism: African Americans in US Department of Agriculture Documentaries, 1921-42, The American Dream and Contemporary Hollywood Cinema, and co-editor of Transmitting the Past: Historical and Cultural Perspectives on Broadcasting. His scholarly articles have appeared in Critical Studies of Media Communication, The Journal of Broadcasting and Electronic Media, Film and History, among others. 